\title{
New insights into the earlier evolutionary history of
}

\section{epiphytic macrolichens}

Qiuxia Yang ${ }^{1,2 \#}$, Yanyan Wang ${ }^{1 \#}$, Robert Lücking ${ }^{3}, \mathrm{H}$. Thorsten Lumbsch ${ }^{4}$, Xin Wang ${ }^{5}$, Zhenyong $\mathrm{Du}^{6}$, Yunkang Chen ${ }^{7,8}$, Ming Bai ${ }^{9}$, Dong Ren ${ }^{10}$, Jiangchun Wei ${ }^{1,2}, \mathrm{Hu} \mathrm{Li}^{6 \dagger}$, Yongjie Wang ${ }^{10 \dagger}$ and Xinli Wei ${ }^{1,2 \uparrow}$ ${ }^{1}$ State Key Laboratory of Mycology, Institute of Microbiology, Chinese Academy of Sciences, Beijing 100101, China.

${ }^{2}$ College of Life Sciences, University of Chinese Academy of Sciences, Beijing 100049, China.

${ }^{3}$ Botanischer Garten und Botanisches Museum, Freie Universität Berlin, 14195 Berlin, Germany.

${ }^{4}$ Science \& Education, The Field Museum, Chicago, IL 60605, USA.

${ }^{5}$ Nanjing Institute of Geology and Palaeontology, Chinese Academy of Sciences, Nanjing 210008, China.

${ }^{6}$ Department of Entomology, MOA Key Lab of Pest Monitoring and Green Management, College of Plant Protection, China Agricultural University, Beijing 100193, China.

${ }^{7}$ School of Agriculture, Ningxia University, Yinchuan, 750021, PR China

${ }^{8}$ College of Plant Protection, Agricultural University of Hebei, Baoding, 071001, PR China

${ }^{9}$ Key Laboratory of Zoological Systematics and Evolution, Institute of Zoology, Chinese Academy of Sciences, Beijing 100101, China.

${ }^{10}$ College of Life Sciences and Academy for Multidisciplinary Studies, Capital Normal University, Beijing 100048, China.

\#Co-first author: Contribution equally to this work.

$\dagger$ For correspondence: tigerleecau@hotmail.com (H.L.), wangyjosmy@foxmail.com (Y.W.) and weixl@im.ac.cn (X.W.).

\section{Abstract}

Lichens are well known as pioneer organisms colonizing bare surfaces such as rocks and therefore have

been hypothesized to play a role in the early formation of terrestrial ecosystems. Given the rarity of

fossil evidence, our understanding of the evolutionary history of lichen-forming fungi is primarily

based on molecular dating approaches. These studies suggest extant clades of macrolichens diversified after the K-Pg boundary. Here we corroborate the mid-Mesozoic fossil Daohugouthallus ciliiferus as an epiphytic macrolichen that predates the K-Pg boundary by 100 Mys. Based on new material and geometric morphometric analysis, we demonstrate that the Jurassic fossil is morphologically most 
similar to Parmeliaceae, but cannot be placed in Parmeliaceae or other similar family-level clades forming macrolichens as these evolved much later. Consequently, a new family, Daohugouthallaceae, is proposed here to accommodate this fossil, which reveals macrolichens may have been diverse long before the Cenozoic diversification of extant lineages.

\section{Introduction}

Lichens are a stable symbiosis composed of fungi and algae and/or cyanobacteria; they also include a diverse microbiome (Spribille et al., 2016; Lücking and Nelsen, 2018; Hawksworth and Grube, 2020).

Lichens are components of mostly terrestrial ecosystems from the polar regions to the tropics (Lumbsch and Rikkinen, 2017), growing on all kinds of substrates, including bark, rock, leaves and soil (Belnap et al., 2001; Brodo et al., 2001; Nash, 2008). Lichens play important roles in ecosystem function, including weathering of rock and accelerating formation of soil (Lindsay, 1978; Chen et al., 2000), fixing carbon and nitrogen from the atmosphere (Wu et al., 2011), and as food source for animals (including humans, Cornelissen et al., 2007). Due to their sensitivity to environmental changes, lichens also are widely used as bioindicator of air pollution and environmental health. The evolutionary history of lichen-forming fungi is poorly understood, due to the sparse fossil record, and has been primarily reconstructed based on molecular dating analyses (Kraichak et al., 2015, 2018; Lücking et al., 2017; Huang et al., 2019; Widhelm et al., 2019; Nelsen et al., 2020). Although these approaches proposed a framework to illustrate how the lichen symbiosis may have evolved, the fossil evidence is indispensable in testing and supplementing the current understandings especially when the earlier fossil was discovered.

To date, about 190 fossils are accepted to represent genuine lichens, and a few are considered ambiguous, i.e. potentially representing lichens (Lücking and Nelsen, 2018). The earliest accepted 
lichen are two crustose lichens from Devonian fossils, i.e. Cyanolichenomycites devonicus and

Chlorolichenomycites salopensis (419-411 Mya), which were inferred to be saxicolous or terricolous (Lücking and Nelsen, 2018). The other earlier lichen is from the Lower Cretaceous, i.e. Honeggeriella complexa (ca. 133 Mya) that was suggested as a squamulose or foliose lichen, although no larger pieces showing its architecture are preserved (Matsunaga et al., 2013; Honegger et al., 2013). A recent study corroborated the lichen property of Daohugouthallus ciliiferus from the Middle Jurassic (ca. 165 Mya) that represented the earliest foliose to subfruticose lichen, based on its external morphology (Fang et al., 2020). Other than this fossil, lichens with foliose and fruticose thalli, the principle forms of macrolichens, have no unambiguous fossil record before the K-Pg boundary (Lücking and Nelsen, 2018), and the oldest accepted macrolichen fossils are from Eocene Baltic amber (38-44 Mya), including foliose and fruticose Parmeliaceae (Kaasalainen et al., 2015, 2017). Ziegler (2001) described and depicted various fragments of presumed parmelioid macrolichens from the Keuper formation (230-200 Mya), a work that has not received much attention and was overlooked by lichenologists (Lücking and Nelsen, 2018). A revision of the data presented in that study did not show conclusive evidence for the presence of macrolichens in the depicted fossils; it also presents methodological issues, such as lack of voucher information and precise links of micrographs to the corresponding fossils. Given this lack of evidence for macrolichen fossils prior to the K-Pg boundary, the question arises about the significance of the Jurassic lichen Daohugouthallus ciliiferus for understanding the evolutionary history of macrolichens in the Mesozoic.

Macrolichens evolved independently in various classes of Basidiomycota (Agaricomycetes: e.g., Cora) and Ascomycota, such as Arthoniomycetes (e.g., Roccella) and Lichinomycetes (e.g., Thyrea). However, most macrolichens are found in the largest class of lichenized Ascomycota, the 
Lecanoromycetes. According to recent molecular clock studies (Nelsen et al., 2020), within Lecanoromycetes, macrolichens evolved independently in at least three separate clades: 1) Umbilicariaceae (subclass Umbilicariomycetidae), with an inferred stem age of 164-150 Mya;2)

Icmadophilaceae (subclass Ostropomycetidae), including macrolichens such as Siphula and Thamnolia, with an inferred stem age of 214-190 Mya; and 3) subclass Lecanoromycetidae, which contain major macrolichen clades such as Cladoniaceae, Coccocarpiaceae, Collemataceae, Pannariaceae, Parmeliaceae, Peltigeraceae, Physciaceae, Ramalinaceae, and Teloschistaceae. Among these, Collemataceae appears to be the oldest, with a stem age of around 145-140 Mya, followed by Pannariaceae and Coccocarpiaceae (140-135 Mya), Peltigeraceae (125-120 Mya), Parmeliaceae (80-75 Mya), Physciaceae (80-60 Mya for macrolichen clades), and Cladoniaceae (60-55 Mya), Teloschistaceae (65-35 Mya for macrolichen clades) and Ramalinaceae (around 50 Mya for macrolichen clades; Nelsen et al. 2020). However, even families that appeared in the Cretaceous, such as Parmeliaceae and Peltigeraceae, were shown to exhibit significantly increased diversification rates after the Cretaceous-Paleogene (K-Pg) boundary (66 Mya, Kraichak et al., 2018; Huang et al., 2019; Widhelm et al., 2019; Nelsen et al., 2020).

Given that macrolichens have evolved in convergent fashion in multiple, often unrelated lineages in Asco- and Basidiomycota, it is vital to clarify the position of Daohugouthallus ciliiferus in reconstructing and understanding the evolution of macrolichens. The oldest known macrolichen fossil, Daohugouthallus ciliiferus, cannot be placed with certainty in extant lineages because fine-scaled diagnostic features, such as hamathecium, ascus, and ascospore structure, cannot be observed. However, techniques such as automated image recognition have allowed to at least analyze morphometric features in a way that allow a quantitative approach to hypothesis testing. In the present 
study, we therefore provide an updated morphological assessment of Daohugouthallus ciliiferus, using an image-based, geometric morphometric analysis to compare the fossil with a range of extant macrolichens. In parallel, we used the large molecular clock analysis by Nelsen et al. (2020), which due to the comprehensive sampling offers a much broader framework than other molecular clock studies including lichen formers (e.g. James et al., 2006; Lutzoni et al., 2018; Kraichak et al., 2018), to reassess stem and crown node ages for major clades of macrolichen formers in the Lecanoromycetes, in comparison to the age of the fossil. As a result, we propose a new family, Daohugouthallaceae, for this fossil.

\section{Results}

Daohugouthallaceae X.L. Wei, X. Wang, D. Ren \& J.C. Wei, fam. nov. (Fig. 1)

\section{Fungal Names FN570853}

Diagnosis: Thallus corticolous, foliose to subfruticose, lobes irregularly branching, lateral black cilia and lobules present. Fungal hyphae thin, algal cells globose, one celled.

Type genus: Daohugouthallus Wang, Krings \& Taylor (Wang et al., 2010)

\section{Type species: Daohugouthallus ciliiferus Wang, Krings \&Taylor (Wang et al., 2010)}

Thallus foliose to subfruticose, about $5 \mathrm{~cm}$ high, $3 \mathrm{~cm}$ wide (Fig. $1 A, E, F$ ); lobes slender, about $5 \mathrm{~mm}$ long and $0.5-1.5 \mathrm{~mm}$ wide, tips tapering, nearly dichotomous to irregular branching, with lateral rhizinate cilia, concolorous to thallus to black, $0.5-1.5 \mathrm{~mm}$ long (Fig. 1B); surface yellow-brown with black spots in some area; lobules present (Fig. 1B); unknown disc-like structure superficial, or nearly terminal, yellow-brown, $0.25-0.5 \mathrm{~mm}$ in diam., sometimes immersed (Fig. 1C). Upper cortex conglutinate, comprising one cell layer, very thin, c. $1 \mu \mathrm{m}$ thick (Fang et al., 2020); algal cells globose to near globose, one-celled, mostly $1.5-2.1 \mu \mathrm{m}$ in diameter, some in framboidal form, anastomosed by 
119 or adhered to the fungal hyphae with simple wall-to-wall mycobiont-photobiont interface; fungal

120 hyphae filamentous, some shriveled, septate, 1.2-1.5 $\mu \mathrm{m}$ wide (Fig. 1G-J; Fang et al., 2020).

121 Substrate: An unidentified gymnosperm branch (Fig. 1D).

Specimens examined: China, Inner Mongolia, Ningcheng County, Shantou Township, near Daohugou

Village, Daohugou 1, Jiulongshan Formation, Callovian-Oxfordian boundary interval, latest Middle

B0476P.

Remarks: The genus Daohugouthallus and species D. ciliiferus were published almost a decade ago

(Wang et al., 2010); however, new anatomical characters were described only recently, based on scanning electron microscopy (Fang et al., 2020). Based on additional materials, phenotypic characters have been reassessed, including morphology and anatomy, and new information about the substrate ecology of the fossil has been added. Structural outline analysis of the thallus included not only the new material of the fossil but also a broad sampling of macrolichens, i.e. 61 extant species and two additional fossils from 12 families and six orders of Lecanoromycetes (Table S1). The geometric morphometric analysis of 140 images resulted in cumulative values for all the principal components were listed in Table S2. The cumulative eigenvalues for the main axes (principal components) with the cumulative variance of the first four principal components amounting to $61.1 \%$ (Table S2), meeting the requirements for geometric morphometric analysis. Among the canonical variate analysis (CVA) for four combinations of the four principal components (individual variances 24.4, 18.0, 10.8,8.0; Fig. 2), the plot combining the first two principal components (cumulative variance 42.4) showed that the fossil Daohugouthallus ciliiferus, in group 2, appeared morphologically closest to foliose Parmeliaceae, in group 3, including the genera Hypotrachyna and Hypogymnia and two foliose Parmeliaceae fossils 
141 (Kaasalainen et al., 2017; Lücking and Nelsen, 2018). However, placement of the fossil within the

142 family Parmeliaceae is not possible, as the inferred stem age of Parmeliaceae is much younger than the

143 age of the fossil (Kraichak et al., 2018; Nelsen et al., 2020). Therefore, a new family,

144 Daohugouthallaceae is proposed, which is tentatively placed in the order Lecanorales given the close

145 morphological similarity to Parmeliaceae.

Significance of the occurrence of Daohugouthallaceae

147 We used the detailed molecular clock tree provided by Nelsen et al. (2020) to illustrate inferred ages

148 for selected family-level clades in the Lecanoromycetes that include macrolichens (Fig. 3). Most of

149 these families have stem node ages relative to the macrolichen genera contained therein substantially younger than 100 Mya, including Caliciaceae, Cladoniaceae, Pannariaceae, Parmeliaceae, Physciaceae, Ramalinaceae, Sphaerophoraceae, Stereocaulaceae and Teloschistaceae. The stem node ages of a few 


\section{Discussion}

\section{The phylogenetic placement of Daohugouthallaceae}

165 The new family based on the fossil lichen Daohugouthallus ciliiferus is tentatively placed in

166 Lecanorales, although sexual reproductive structures are missing that would allow to test this

placement. Ascomata, asci and ascospores are crucial to assess systematic affinities within

Lecanoromycetes (Hafellner, 1994) and have been demonstrated in fungal fossils as old as 400 Mya

(Taylor et al., 2005). Apothecia-like structures seem to be present in the fossil (Fig. 1C), but no

structures interpretable as asci and ascospores were detectable. The thin nature of compression fossils

like Daohugouthallus cilifferus makes it difficult for such structures to be preserved, if they were

indeed present in the organism. Molecular phylogeny has also shaped the systematics of

Lecanoromycetes (Thell et al., 2009; Miadlikowska et al., 2011; Leavitt et al., 2015; Magain et al.,

174

2017). DNA has been presumably extracted and amplified from fossils as old as 250 Mya (Cano et al., 1993; Fish et al., 2002), but these findings have been challenged and considered artifactual (Pääbo et al., 2004). Successful DNA extraction from permineralized or compression fossils as old as

Daohugouthallus ciliiferus seems impossible and so this is not an avenue that could be followed to clarify the systematic affinities of this and other lichen or fungal fossils.

In lieu of sexual reproductive structure evidence to clarify the potential affinities of

Daohugouthallaceae, our geometric morphometric analysis seems a suitable alternative to provide at least a hypothesis based on quantitative data. This approach, based on homologous landmarks or structural outlines (Rohlf and Marcus, 1993), was here apparently used for the first time in this context but has been widely used in entomology (Bai et al., 2012, 2014; Ren et al., 2017). However, it requires a careful approach to data assessment (Fox et al., 2020). The CVA plots (Fig. 2) based on the comparison with homologous landmarks of 61 extant macrolichens and two Parmeliaceae fossils 

of a new, monogeneric family for this fossil therefore seems justified.

The apparently smaller algal cells $(1.5-2.1 \mu \mathrm{m}$ in diam.) and thinner fungal hyphae (1.2-1.5 $\mu \mathrm{m}$ wide) structures.

\section{The importance of Daohugouthallaceae for our understanding of macrolichen evolution}

Among the new specimens of Daohugouthallus ciliiferus collected from the type locality, one thallus was found attached to the branch of an unidentified cone-bearing gymnosperm fossil. The Daohugou paleoenvironment has been analyzed to be a gymnosperm-dominated forest vegetation (Ren and Krzeminski, 2002; Tan and Ren, 2002; Zhang et al., 2006), and Daohugouthallus ciliiferus has been reconstructed to be epiphytic on gymnosperms due to its association with a small seed cone (Wang et al., 2010), but in the original study the two fossils were not directly connected. Our new specimen (Fig. 1A) clearly shows the thallus growing directly on a thin branch of a gymnosperm with an associated cone (Fig. 1D), possibly representing a conifer, suggesting that gymnosperms may have served as substrate for epiphytic macrolichens already in the Jurassic. Extant lichenized clades that are largely epiphytic have been dated back to as far as the early Jurassic, such as microlichens in the Graphidaceae, Pyrenulaceae, and Trypetheliaceae (Lücking et al., 2013; Beimforde et al., 2014;

Kraichak et al., 2018; Nelsen et al., 2019, 2020). However, the oldest extant macrolichen clade, Umbilicaria, is almost exclusively rock-dwelling (saxicolous), and while extant macrolichen vary 
greatly in substrate choice (Belnap et al., 2001; Brodo et al., 2001; Nash, 2008), extant epiphytic

macrolichen clades are consistently younger than the K-Pg boundary and only since then have evolved and diversified between 190-160 Mya in the Early to Middle Jurassic (Leslie et al., 2018) into the epiphytic macrolichens, has been estimated at 300-250 Mya (Nelsen and Lücking, 2018; Kraichak et al., 2018; Lutzoni et al., 2018; Nelsen et al., 2020), and so it is conceivable that epiphytic macrolichens even older than Daohugouthallus ciliiferus may have existed.

The diversification of Lecanoromycetes coincides with the period after the end-Permian extinction.

Before that time, diverse Permian forests existed around the world (Behrensmeyer and Hook, 1992;

Gulbranson et al., 2012; Wang et al., 2012). While these could have provided potential environments for epiphytic macrolichens, there is no fossil record that would support such an assumption. The endvegetation at that time, with diverse forests already in the Late Triassic and into the Jurassic (Rees et 
165 Mya Daohugouthallus ciliiferus fossil, thus providing the earliest known evidence of the existence

of epiphytic macrolichens. Notably, various other groups of organisms underwent radiations in this

\section{Materials and Methods}

242 Geological context: Specimens in this study were collected from the Daohugou locality of the

Experimental methods: The lichen fossils were examined and photographed using an Olympus SZX7

248 Stereomicroscope attached to a Mshot MD50 digital camera system. For selected fossil we made cross 
Specimen repository: Fossil specimens of Daohugouthallus ciliiferus (CNU-LICHEN-NN2019001,

Multidisciplinary Studies, Capital Normal University, in Beijing, China.

Geometric morphometrics: Absence of diagnostic characters such as ascomata, asci and ascospores in

(Kaasalainen et al., 2017). 
274 divided into five groups according to lobes types: microfoliose group, the Daohugouthallus ciliiferus

275 fossil group, a long branches group, a wide-lobed group, and a fruticose group (Table S3). The selected

276 images were two-dimensional graphs with two views of the front or back of the thallus where the

277 branch tips were clearly recognizable. To orientate the images in the same direction, they were adjusted

278 so that the end of the branches faced right. Images were named in a unified format: growth type-order-

279 family-genus-species (sample number) except for the two selected reference fossil images only

280 corresponding to family name.

281 As stated, the external forms were represented by one curve extracted from the end of branches or

282 lobes and the curve was resampled into 60 semi-landmarks by length (Fig. S2). The curves and semilandmarks were digitized using TPS-DIG 2.05 (Rohlf, 2006). To merge all semi-landmarks into the same data file to produce the data set for morphological analysis, the data file was opened as text file to convert the semi-landmarks to landmarks, by deleting the line with the curve number and point number and replacing the landmark number by the point number (Tong et al., 2021).

MORPHO J 1.06a (Klingenberg, 2011) was used for subsequent analysis of the data set. Through

Procrustes analysis, the morphological data of all test features were placed in the same dimensional 
296 General: We thank Mr. Yijie Tong for assisting in geometric morphometrics analysis, Dr. Chunli Li

297 for assisting in taking SEM photos, Ms. Hong Deng and Ms. Haijuan Chen for lending and taking

298 photos of lichen specimens in HMAS-L, Ms. Xiaoran Zuo for drawing the habitus reconstruction

299 picture Fig. 5, and Mr. Jujie Guo for making the fossil slices.

300 Funding: This work was supported by the National Natural Science Foundation of China (grant

Author contributions: QXY: Literatures investigation, geometric morphometric analysis, molecular resources collection, supervision, funding acquisition, validation, draft review and editing; XLW:

314 Conceptualization, supervision, geometric morphometric analysis, SEM photos taking and analysis,

315 data curation, funding acquisition, project administration, validation, original draft writing, review and 316 editing.

\section{References}


318 Ahti T, Stenroos S, Filho LX. 1993. The lichen family Cladoniaceae in Paraiba, Pernambuco and Sergipe,

Bai M, Ahrens D, Yang XK, Ren D. 2012. New fossil evidence of the early diversification of scarabs: Alloioscarabaeus cheni (Coleoptera: Scarabaeoidea) from the Middle Jurassic of Inner Mongolia, China. Insect Science 19: 159-171. DOI: https://doi.org/10.1111/j.1744-7917.2011.01460.x

Bai M, Yang XK, Li J, Wang WC. 2014. Geometric Morphometrics, a super scientific computing tool in morphology comparison. Chinese Science Bulletin (Chinese Version) 59: 887-894. DOI:

Behrensmeyer AK, Hook RW. 1992. Paleoenvironmental contexts and taphonomic modes. In: 
340 on the avian stem lineage. PLoS Biology 12(5): e1001853. DOI: https://doi.org/10.1371/journal.pbio.1001853

342 Bonis NR, Kürschner WM. 2012. Vegetation history, diversity patterns, and climate change across the Triassic/Jurassic boundary. Paleobiology 38(2): 240-264. DOI: https://doi.org/10.1666/09071.1

Brodo IM, Sharnoff SD, Sharnoff S. 2001. Lichens of North America. Yale University Press, New Haven, CT, p. 795. DOI: https://doi.org/10.29173/bluejay5827

Cano RJ, Poinar HN, Pieniazek NJ, Acra A, Poinar GO. 1993. Amplification and sequencing of DNA from a https://doi.org/10.1038/363536a0

Chen J, Blume H, Beyer L. 2000. Weathering of rocks induced by lichen colonization-a review. Catena 39: 121-146. DOI: https://doi.org/10.1016/S0341-8162(99)00085-5

Close RA, Friedman M, Lloyd GT, Benson RBJ. 2015. Evidence for a mid-Jurassic adaptive radiation in mammals. Current Biology 25 (16): 2137-2142. DOI: https://doi.org/10.1016/j.cub.2015.06.047 review of bryophyte and lichen traits that drive biogeochemistry. Annals of Botany 99(5): 987-1001.

Crisp MD, Cook LG. 2011. Cenozoic extinctions account for the low diversity of extant gymnosperms

Damborenea SE, Echevarría J, Ros-Franch S. 2017. Biotic recovery after the end-Triassic extinction event: Evidence from marine bivalves of the Neuquén Basin, Argentina. Palaeogeography,

487:

93-104.

DOI: 
Erwin DH. 2001. Lessons from the past: Biotic recoveries from mass extinctions. Proceedings of the

Esslinger TL. 1985. Studies in the lichen family Physciaceae .6. 2 Species New to North-America.

Mycotaxon 23(1-4): 219-222.

Fang H, Labandeira CC, Ma YM, Zheng BY, Ren D, Wei XL, Liu JX, Wang YJ. 2020. Lichen mimesis in mid-Mesozoic lacewings. eLife 9: e59007. DOI: https://doi.org/10.7554/eLife.59007

Fish SA, Shepherd TJ, McGenity TJ, Grant WD. 2002. Recovery of 16S ribosomal RNA gene fragments from ancient halite. Nature 417(6887): 432-436. DOI: https://doi.org/10.1038/417432a

Fox NS, Veneracion JJ, Blois JL. 2020. Are geometric morphometric analyses replicable? Evaluating landmark measurement error and its impact on extant and fossil Microtus classification. Ecology and

Goward T, McCune B. 2007. Hypogymnia canadensis (Parmeliaceae), a new lichen from the Pacific Coast of North America. Bryologist 110(4): 808-811. DOI: https://doi.org/10.1639/0007-

Gulbranson EL, Isbell JL, Taylor EL, Ryberg PE, Taylor TN, Flaig PP. 2012. Permian polar forests: https://doi.org/10.1111/j.1472-4669.2012.00338.x 
He HY, Wang XL, Zhou ZH, Zhu RX, Jin F, Wang F, Ding X, Boven A. 2004. 40Ar/ 39Ar dating of ignimbrite from Inner Mongolia, northeastern China, indicates a post-Middle Jurassic age for the

DOI:

Honegger R, Edwards D, Axe L. 2013. The earliest records of internally stratified cyanobacterial and

Huang JP, Kraichak EK, Leavitt SD, Nelsen MP, Lumbsch HT. 2019. Accelerated diversifications in three diverse families of morphologically complex lichen-forming fungi link to major historical 
Alectorioid morphologies in paleogene lichens: new evidence and re-evaluation of the fossil

Alectoria

succini

Mägdefrau.

PLoS

One

10

(6): $\mathrm{e} 0129526$.

DOI:

https://doi.org/10.1371/journal.pone.0129526

Kaasalainen U, Schmidt AR, Rikkinen J. 2017. Diversity and ecological adaptations in Palaeogene

lichens. Nature Plants 3: 17049. DOI: https://doi.org/10.1038/nplants.2017.49

Klingenberg CP. 2011. Computer program note Morphoj: an integrated software package for geometric

11: 353-357. DOI: https://doi.org/10.1111/j.1755-

$\underline{0998.2010 .02924 . x}$

Kraichak E, Divakar PK, Crespo A, Leavitt SD, Nelsen MP, Lücking R, Lumbsch HT. 2015. A tale of two hyper-diversities: diversification dynamics of the two largest families of lichenized fungi.

Kraichak E, Huang JP, Nelsen M, Leavitt SD, Lumbsch HT. 2018. A revised classification of orders and Scientific Reports 5: 10028. DOI: https://doi.org/10.1038/srep10028 
Lindsay D. 1978. The role of lichens in Antarctic ecosystems. Bryologist 81: 268-276. DOI: https://doi.org/10.2307/3242188

Liu YQ, Liu YX, Ji S, Yang ZQ. 2006. U-Pb zircon age for the Daohugou Biota at Ningcheng of Inner Mongolia and comments on related issues. Chinese Science Bulletin 51, 2634-2644. DOI: https://doi.org/10.1007/s11434-006-2165-2

Lücking R, Tehler A, Bungartz F, Rivas Plata E, Lumbsch HT. 2013. Journey from the West: did tropical Graphidaceae (lichenized Ascomycota: Ostropales) evolve from a saxicolous ancestor along the American Pacific coast? American Journal of Botany 100(5): 844-856. DOI: https://doi.org/10.3732/ajb.1200548

Lücking R, Hodkinson BP, Leavitt SD. 2017. The 2016 classification of lichenized fungi in the Ascomycota and Basidiomycota - Approaching one thousand genera. The Bryologist 119: 361-416. DOI: https://doi.org/10.1639/0007-2745-119.4.361

Lücking R, Nelsen MP. 2018. Ediacarans, protolichens, and lichen-derived Penicillium: a critical reassessment of the evolution of lichenization in fungi. In: Transformative paleobotany, pp. 551-590. Academic Press. DOI: https://doi.org/10.1016/B978-0-12-813012-4.00023-1

Lumbsch HT, Rikkinen J. 2017. Evolution of lichens. In: Dighton J, White J, Boca Raton FL (edds), The fungal community: its organization and role in the ecosystem. CRC Press: 53-62. DOI: https://doi.org/10.1201/9781315119496-5

Lutzoni F, Nowak MD, Alfaro ME, Reeb V, Miadlikowska J, Krug M, Arnold AE, Lewis LA, Swofford DL, Hibbett D, Hilu K, James TY, Quandt D, Magallón S. 2018. Contemporaneous radiations of fungi and plants linked to symbiosis. Nature Communications 9: 5451. DOI: https://doi.org/10.1038/s41467-018-07849-9 
Magain N, Madlikowska J, Mueller O, Gajdeczka M, Truong C, Salamov AA, Dubchak I, Grigoriev IV, Goffinet B, Sérusiaux E, Lutzoni F. 2017. Conserved genomic collinearity as a source of broadly applicable, fast evolving, markers to resolve species complexes: A case study using the lichenforming genus Peltigera section Polydactylon. Molecular Phylogenetics and Evolution 117: 10-29. DOI: https://doi.org/10.1016/j.ympev.2017.08.013

Matsunaga KKS, Stockey RA, Tomescu AMF. 2013. Honeggeriella complexa gen. et sp. nov., a heteromerous lichen from the lower cretaceous of Vancouver Island (British Columbia, Canada) American Journal of Botany 100 (2): 450-459. DOI: https://doi.org/10.3732/ajb.1200470

McCune B, Rosentreter R, Ponzetti JM, Shaw DC. 2000. Epiphyte habitats in an old conifer forest in Western Washington, USA. Bryologist 103 (3): 417-427. DOI: https://doi.org/10.1639/0007$\underline{\text { 2745(2000)103[0417:EHIAOC]2.0.CO;2 }}$

Miadlikowska J, Schoch CL, KageyamaSA, MolnarK, LutzoniF, McCune B. 2011. Hypogymnia phylogeny, including Cavernularia, reveals biogeographic structure. Bryologist 114 (2): 392-400. DOI: https://doi.org/10.1639/0007-2745-114.2.392

Nash TH III. 2008. Lichen Biology. 2nd ed. Cambridge, UK: Cambridge University Press.

Nelsen MP, Lücking R, Boyce CK, Lumbsch HT, Ree RH. 2019. No support for the emergence of lichens prior to the evolution of vascular plants. Geobiology 18, 3-13. DOI: https://doi.org/10.1111/gbi.12369

Nelsen MP, Lücking R, Boyce CK, Lumbsch HT, Ree RH. 2020. The macroevolutionary dynamics of symbiotic and phenotypic diversification in lichens. Proceedings of the National Academy of Sciences 117(35): 21495-21503. DOI: https://doi.org/10.1073/pnas.2001913117

Nie Y, Foster CSP, Zhu TQ, Yao R, Duchêne DA, Ho SYW, Zhong BJ. 2020. Accounting for uncertainty 
in the evolutionary timescale of green plants through clock-partitioning and fossil calibration strategies. Systematic Biology 69 (1): 1-16. DOI: https://doi.org/10.1093/sysbio/syz032

Pääbo S, Poinar H, Serre D, Jaenicke-Despres V, Hebler J, Rohland N, Kuch M, Krause J, Vigilant L, Hofreiter M. 2004. Genetic analyses from ancient DNA. Annual Review of Genetics 38(1): 645-679. DOI: https://doi.org/10.1146/annurev.genet.37.110801.143214

Rees PM, Noto CR, Parrish JM, Parrish JT. 2004. Late Jurassic climates, vegetation, and dinosaur distributions. The Journal of Geology 112(6): 643-653. DOI: https://doi.org/10.1086/424577

Ren D, Krzeminski W. 2002. Eoptychopteridae (Diptera) from the Middle Jurassic of China. Annales Zoologici 52: 207-210.

Ren D, Shih CK, Gao TP, Wang YJ, Yao YZ. 2019. Rhythms of insect evolution-evidence from the Jurassic and Cretaceous in Northern China. Wiley Blackwell, New York. DOI: https://doi.org/10.1002/9781119427957

Ren J, Bai M, Yang XK, Zhang RZ, Ge SQ. 2017. Geometric morphometrics analysis of the hind wing of leaf beetles: proximal and distal parts are separate modules. ZooKeys 685: 131-149. DOI: https://doi.org/10.3897/zookeys.685.13084

Rohlf FJ. 2006. tpsDig, Digitize Landmarks and Outlines, Version 2.05. Stony Brook, NY: Department of Ecology and Evolution, State University of New York.

Rohlf FJ, Marcus LF. 1993. A revolution in morphometrics. Trends in Ecology \& Evolution 8: 129-132. DOI: https://doi.org/10.1016/0169-5347(93)90024-J

Sellwood BW, Valdes PJ. 2008. Jurassic climates. Proceedings of the Geologists' Association 119(1): 517. DOI: $\underline{\text { https://doi.org/10.1016/S0016-7878(59)80068-7 }}$

Spribille T, Muggia L. 2013. Expanded taxon sampling disentangles evolutionary relationships and 

reveals a new family in Peltigerales (Lecanoromycetidae, Ascomycota). Fungal Diversity 58: 171184. DOI: https://doi.org/10.1007/s13225-012-0206-5

Spribille T, Tuovinen V, Resl P, Vanderpool D, Wolinski H, Aime MC, Schneider K, Stabentheiner E, Toome-Heller M, Thor G, Mayrhofer H. 2016. Basidiomycete yeasts in the cortex of ascomycete macrolichens. Science 353(6298): 488-492. DOI: https://doi.org/10.1126/science.aaf8287

Tan JJ, Ren D. 2002. Palaeoecology of insect community from Middle Jurassic Jiulongshan Formation in Ningcheng County, Inner Mongolia, China. Acta Zootaxonomica Sinica 27: 428-434.

Taylor TN, Hass H, Kerp H, Krings M, Hanlin RT. 2005. Perithecial ascomycetes from the 400 million year old Rhynie chert: an example of ancestral polymorphism. Mycologia 97(1): 269-285. DOI: https://doi.org/10.1080/15572536.2006.11832862

Thell A, Högnabba F, Elix JA, Feuerer T, Kärnefelt I, Myllys L, Randlane T, Andres Saag A, Stenroos S, Ahti T, Seaward MRD. 2009. Phylogeny of the cetrarioid core (Parmeliaceae)based on five genetic markers. The Lichenologist 41: 489-511. DOI: https://doi.org/10.1017/S0024282909990090

Tong YJ, Yang HD, Jenkins Shaw J, Yang XK, Bai M. 2021. The relationship between genus/species richness and morphological diversity among subfamilies of jewel beetles. Insects 12(1): 24. DOI: https://doi.org/10.3390/insects12010024

Wang J, Pfefferkorn HW, Zhang Y, Feng Z. 2012. Permian vegetational Pompeii from Inner Mongolia and its implications for landscape paleoecology and paleobiogeography of Cathaysia. Proceedings of the National Academy of Sciences 109(13): 4927-4932. DOI: https://doi.org/10.1073/pnas.1115076109

Wang Y, Mosbrugger V, Zhang H. 2005. Early to Middle Jurassic vegetation and climatic events in the Qaidam Basin, Northwest China. Palaeogeography, Palaeoclimatology, Palaeoecology 224(1-3): 
Wang X, Krings M, Taylor NT. 2010. A thalloid organism with possible lichen affinity from the Jurassic of northeastern China. Rev. Review of Palaeobotany and Palynology 162: 591-598. DOI: https://doi.org/10.1016/j.revpalbo.2010.07.005

Wei XL, Leavitt S, Huang JP, Esslinger TL, Wang LS, Moncada B, Lücking R, Divakar PK, Lumbsch HT. 2017. Parallel Miocene-dominated diversification of the lichen-forming fungal genus Oropogon (Parmeliaceae, Ascomycota) in different continents. Taxon 66 (6): 1269-1281. DOI: https://doi.org/10.1038/s41598-019-45455-x

Willis KJ, Niklas KJ. 2004. The role of Quaternary environmental change in plant macroevolution: the https://doi.org/10.1098/rstb.2003.1387 soil crusts. Microbial Ecology 62: 715-724. DOI: https://doi.org/10.1007/s00248-011-9828-5 

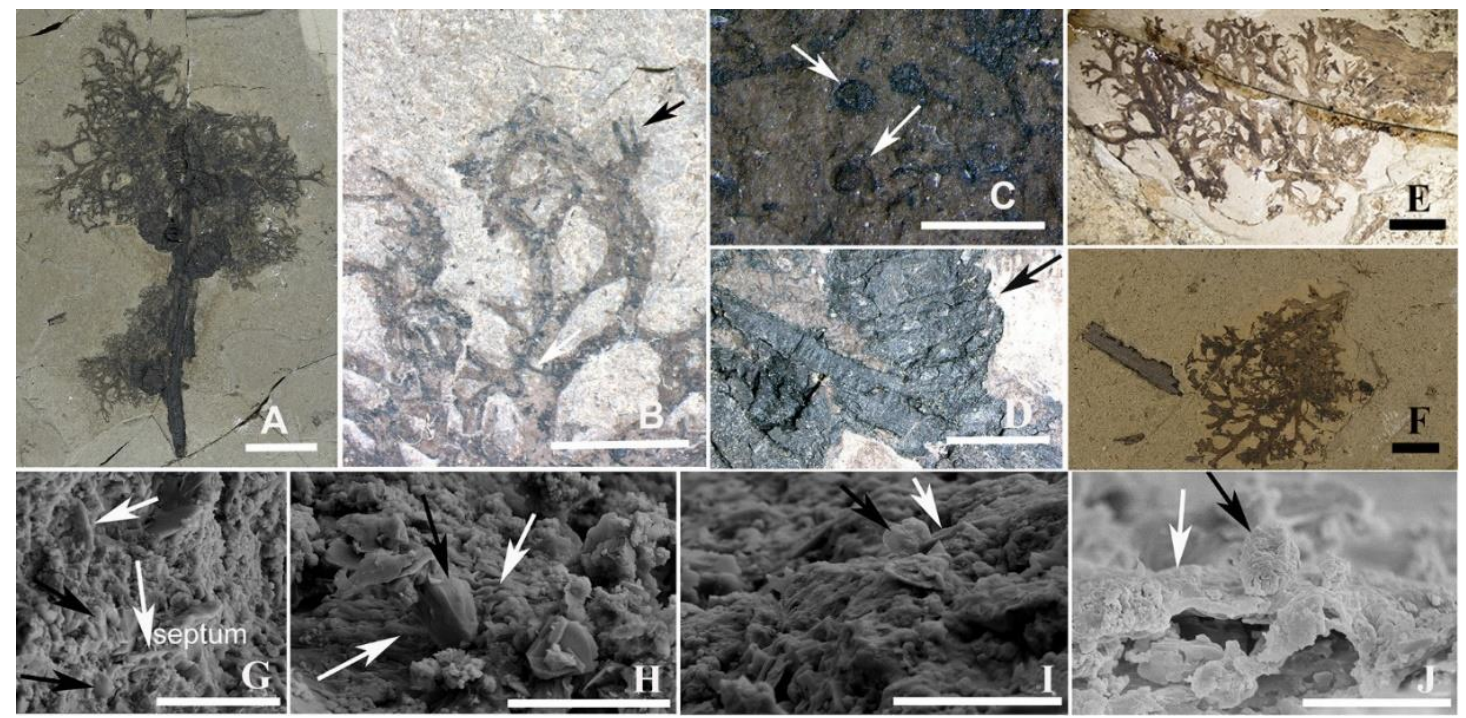

Fig. 1. Photos of lichen Daohugouthallus ciliiferus. (A). External morphology of lichen thallus directly growing on the gymnosperm branch, CNU-LICHEN-NN2020001. (B). Marginal rhizinate cilia and lobules marked by white and black arrows, respectively, CNU-LICHEN-NN2020001; (C). Superficial and nearly immersed unknown disc-like structure, CNU-LICHEN-NN2020001. (D). Gymnosperm branch with seed cones marked by black arrow, CNU-LICHEN-NN2020001. (E). External morphology of lichen thallus of CNU-LICHEN-NN2019001. (F). External morphology of lichen thallus of CNU-LICHEN-NN2019002. Scanning electron microscopy (SEM) of Daohugouthallus ciliiferus. (G-H). CNU-LICHEN-NN2020001. (I). CNU-LICHEN-NN2020002. (J). CNU-LICHEN-NN2019001. Scale bars: The fungal hyphae and algal cells indicated by white and black arrows, respectively. A, B, E=1cm; C, F=5mm; $D=1 \mathrm{~mm} ; \mathrm{G}=5 \mu \mathrm{m} ; \mathrm{H}-\mathrm{J}=4 \mu \mathrm{m}$. 

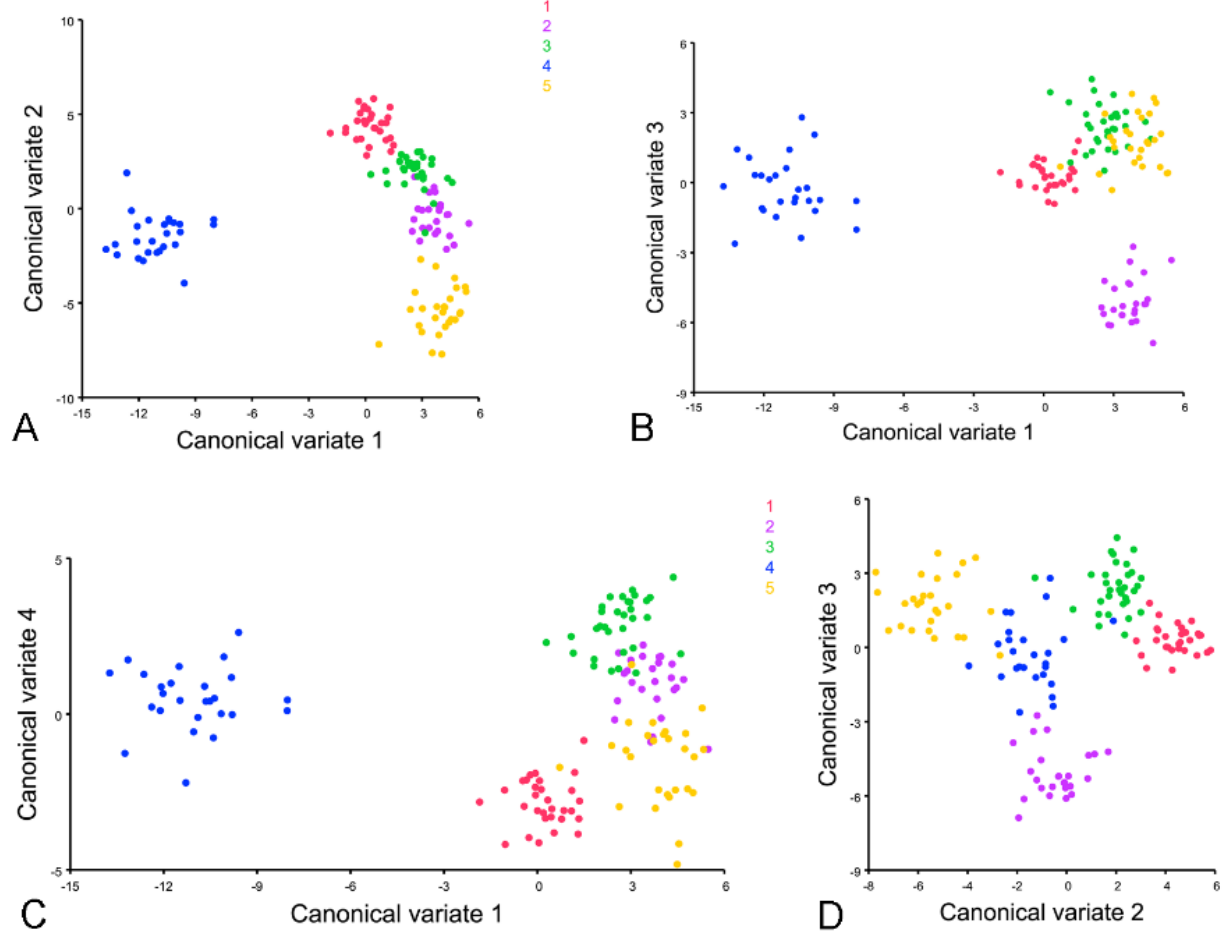

Fig. 2. CVA plots based on the geometric morphometrics analysis (the first four principal components). (A). CVA plot based on the highest Cumulative value 42.385 corresponding to the sum of the first principal component with the Variance value 24.433 and the second (17.952). (B). CVA plot based on the Cumulative value 35.271 corresponding to the sum of the first principal component with the Variance value 24.433 and the third (10.838). (C). CVA plot based on the Cumulative value 32.457 corresponding to the sum of the first principal component with the Variance value 24.433 and the fourth (8.024). (D). CVA plot based on the Cumulative value 28.79 corresponding to the sum of the second principal component with the Variance value 17.952 and the third (10.838). Different colors represented different groups (Table S3). The distance showed the degree of similarity between different groups. Group 1 in red: FO-C-Physcia (Physciaceae, Caliciales)/FO-P-Coccocarpia (Coccocarpiaceae, Peltigerales)/FO-P-Pannaria (Pannariaceae, Peltigerales), group 2 in purple: FO-L-Daohugouthallus, group 3 in green: FO-L-Accepted foliose Parmeliaceae fossil/Hypotrachyna/Hypogymnia (Parmeliaceae, Lecanorales), group 4 in blue: FO-P-Peltigera

562 (Peltigeraceae,Peltigerales)/Lobaria/Sticta (Lobariaceae, Peltigerales)/FO-U-Umbilicaria

563 (Umbilicariaceae, Umbilicariales), group 5 in orange: FR-L- Accepted fruticose Parmeliaceae fossil/Cladonia (Cladoniaceae, Lecanorales)/Evernia (Parmeliaceae, Lecanorales)/Ramalina (Icmadophilaceae, Pertusariales)/FR-T-Teloschistes (Teloschistaceae, Teloschistales). 


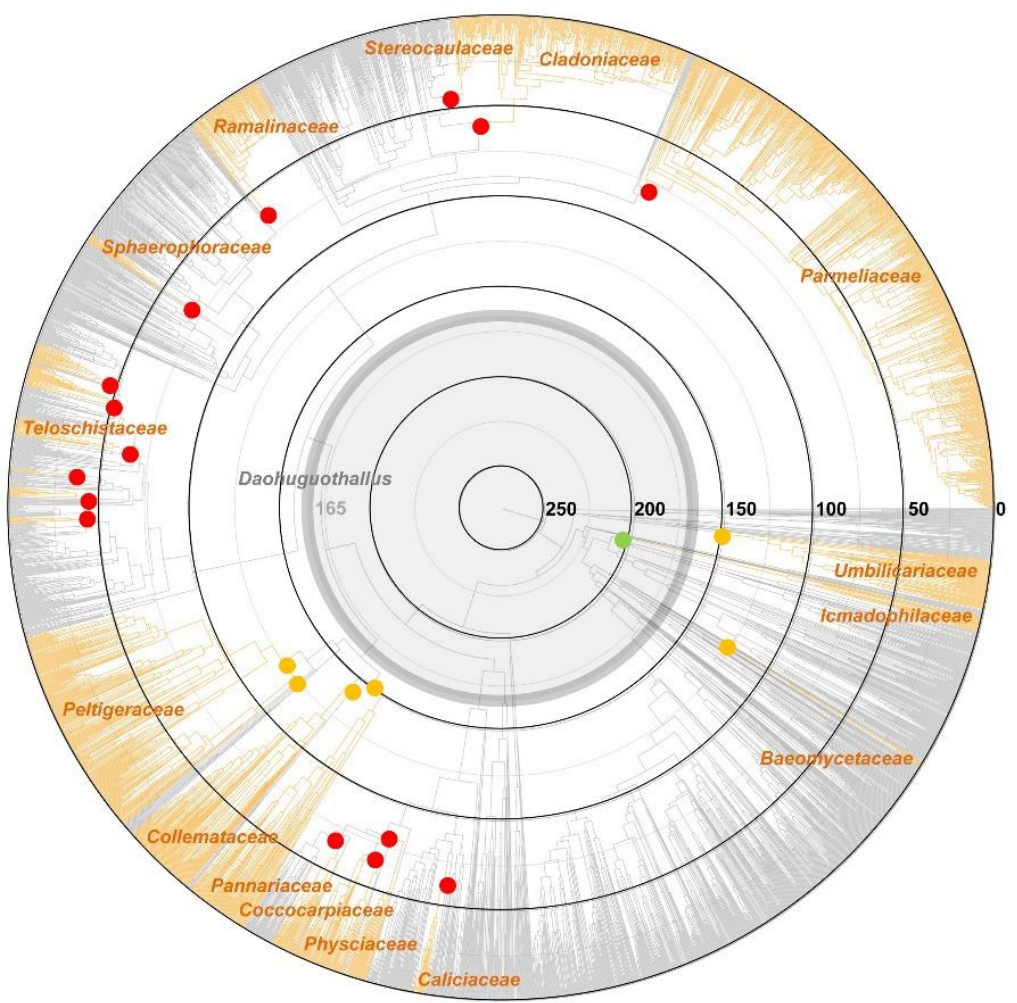

Fig. 3. Time-calibrated ML phylogeny of 3,373 Lecanoromycetes fungi (based on Nelsen et al., 2020). Macrolichen lineages are indicated in orange and the corresponding families are indicated.

570 The temporal placement of the Daohugouthallus ciliiferus fossil is marked by the bold gray circle. For details see Suppl. Fig. S1. 

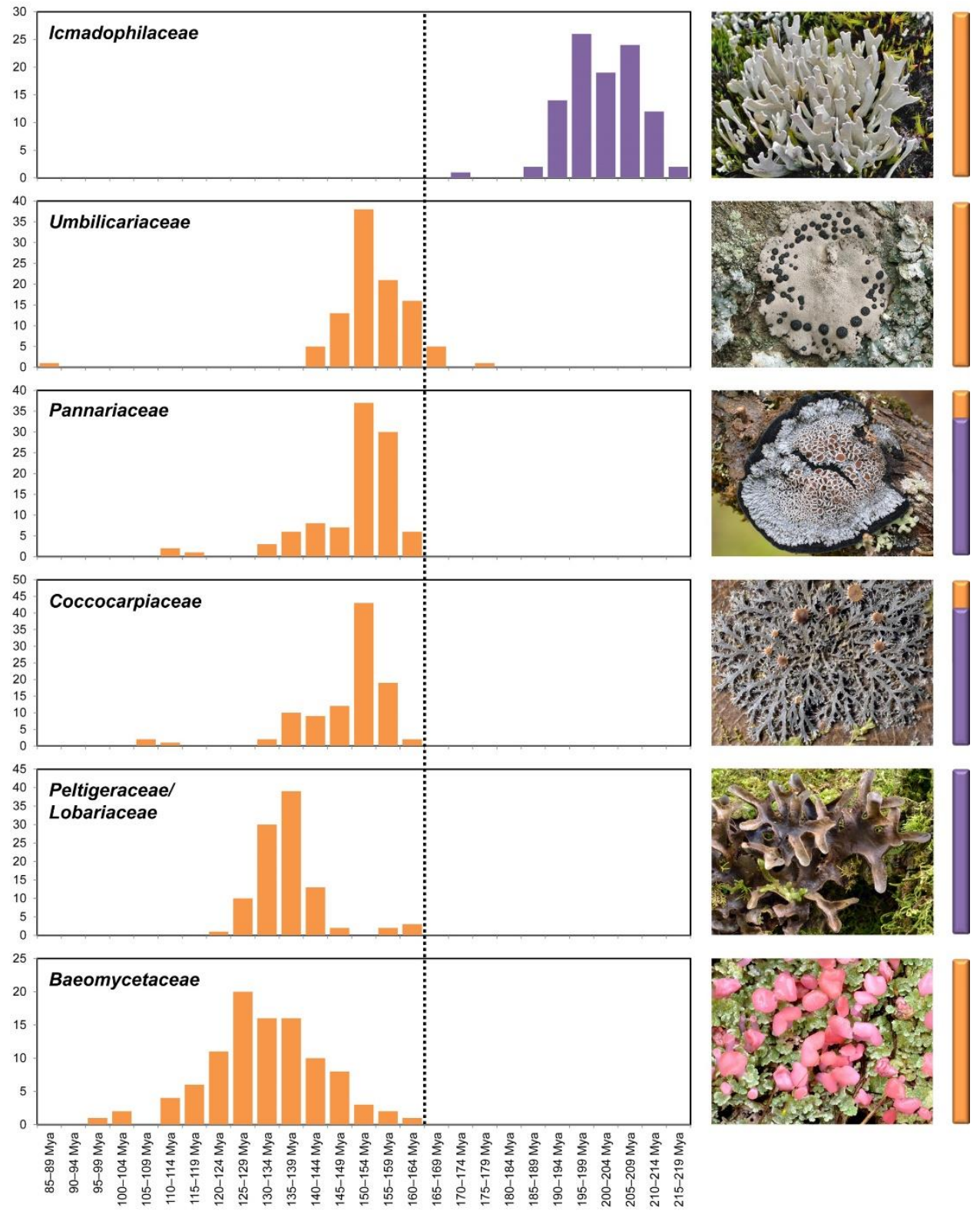

Fig. 4. Distribution of inferred divergence times for the oldest extant macrolichen families (based on Nelsen et al., 2020). The external morphology of selected representatives of each family is depicted to the right. The dotted line indicates the temporal placement of the Daohugouthallus ciliiferus fossil. The first three families are likely as old or older than the fossil but do not fit morphologically and/or ecologically. The best morphological and ecological fit are Peltigeraceae, in particular lobarioid lineages, but that family is significantly younger. 


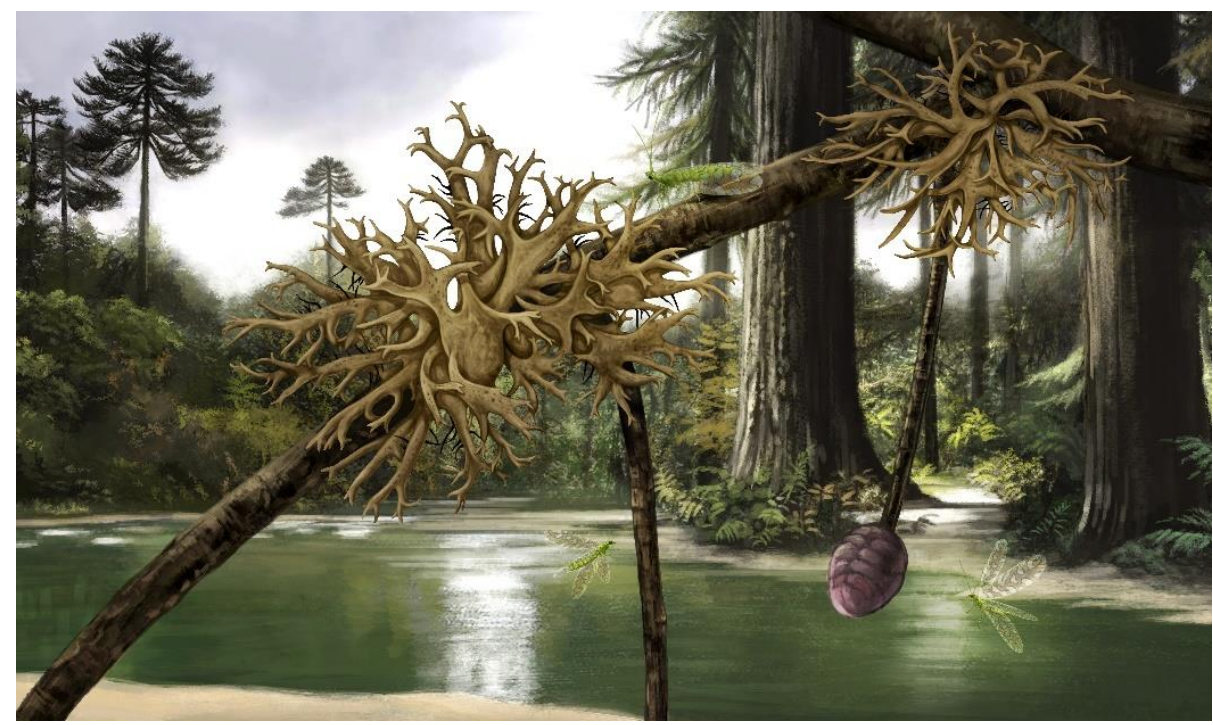

$580 \quad$ Fig. 5. Habitus reconstruction of the lichen Daohugouthallus ciliiferus growing on

581 gymnosperm branches. Drawing by Xiaoran Zuo. 